
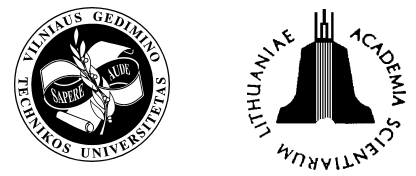

\title{
TRANSFORMATIONS IN RISK MANAGEMENT OF CURRENCY EXCHANGE IN LITHUANIAN COMMERCIAL BANKS
}

\author{
Jonas Nedzvedskas ${ }^{1}$, Povilas Aniūnas ${ }^{2 *}$ \\ ${ }^{1}$ Faculty of Economics and Law, Kaunas College, Puodžiu g. 11, LT-44295 Kaunas, Lithuania. \\ E-mail: jonas.nedzveckas@ktu.lt \\ ${ }^{2}$ Dept of Finance and Accounting, Kaunas Faculty of Humanities, Vilnius University, Muitinès g. 8, \\ LT-44280 Kaunas, Lithuania.E-mail:povilas.aniunas@vukhf.lt
}

Received 12 Febr 2007; accepted 25 July 2007

\begin{abstract}
After the adoption of International Convergence of Capital Measurement and Capital Standards (widely known as Basel II requirements) in 2004 the risk management in commercial banks has changed dramatically. Lithuanian commercial banks are in transitional period now adapting their risk management systems to Basel II requirements. Market risk is considered one of the key risks in bank risk management structure, so proper management of market risk is essential for a modern bank. Currency exchange risk usually is the main component of market risk. Currency exchange risk management in Lithuanian commercial banks was not good enough; also the Central Bank's regulatory limits were liberal. But after the adoption of Basel II requirements, the entire risk management system is transforming and currency exchange risk management is affected. The objective of this paper is to demonstrate the transformations of currency exchange in Lithuanian commercial banks and propose an effective model for commercial banking. These transformations are performed in the regulatory system imposed by the Central Bank of Lithuania and through transformations of the bank's internal risk management system moving to internal (usually VaR based) models. VaR models are considered as modern methods for risk management. These models proposed by Central bank or other authorities for internal and statutory risk management in commercial banks. In this article, the proposed variation-covariation VaR model was tested with real data using the back-testing method. Back-testing showed that the proposed model is reliable enough, because the number of mismatches was less than $5 \%$ in all tested currency pairs during all testing. In most currency pairs mismatches percentage was lower than $3 \%$. Back-testing results confirm that the VaR method is reliable enough for day-to-day using by financial institutions and traders.
\end{abstract}

Keywords: currency exchange risk, Value-at-Risk (VaR), Basel committee, commercial banking, Lithuania.

\section{Introduction}

Risk management approaches in commercial banks were changing when first commercial bank started its activities. Banks usually perform intermediary and payment functions and that distinguish them from other businesses [1]. The main product of such bank is intermediation between those with surplus liquidity, who make deposits, and those in need of liquidity, who borrow from the bank [2, 3]. For banks where intermediation is the principal function, risk management consists largely of good asset-liability management. Such banking (and risk management) approaches were very important up to the 1980s. All risk management and banking business were devoted to good asset-liability management techniques [4-7].

\footnotetext{
* Corresponding author
}

But in modern banking main activities changed dramatically and modern banks have moved into new areas of offbalance sheet banking. As a consequence, risk management has expanded to include not just asset-liability management, but the management of risks arising from off-balance sheet activity.

Hence in modern bank credit risk is still the main risk, but importance of other risks (especially market risk) are constantly growing and modern banks are trying to manage market risk with modern mathematical-statistical models.

On the other hand, international and national commercial banks regulators are trying to enforce modern risk management methods in commercial banks. Main international banks regulator is Basel Committee, which issues guidance for central banks how to control commercial banks and for commercial banks how to manage risk and banking activities. Basel Committee proposes and adopts International 
Convergence of Capital Measurement and Capital Standards (known as Basel $\mathrm{I}^{1}$, Basel $\mathrm{II}^{2}$, and Basel $\mathrm{III}^{3}$ ). This accord is not compulsory for commercial banks directly, but in most countries centrals are imposing these requirements through regulatory system.

Lithuania commercial banks are in the transition between Basel I and Basel II. Till 2008 commercial bank can choose whether to use Basel I or Basel II system, but from 20080101 Basel II requirements will be compulsory for all banking institutions in Lithuania.

Also Basel committee is preparing Basel III regulations were market risk will be evaluated using mostly the Valueat-Risk (VaR) methodology. Lithuania central bank already trying to enforce commercial banks use modern risk management (mostly VaR based) models for internal or external (reporting) purposes.

The goal of the research is to describe currency risk management transition in Lithuanian commercial banks and propose the VaR model for currency risk management in financial institution. Therefore the object of the research is currency risk and currency risk management.

\section{Basel committee and currency exchange risk}

The Basel Committee began to address the treatment of market risks in a 1993 consultative document, and the outcome was the 1996 Amendment of Basel 118 to be implemented by international banks by 1998 [8]. It introduced a more direct treatment of off-balance sheet items rather than converting them into credit risk equivalents, as was done in the original Basel I. Market risk is the risk that changes in market prices will cause losses in positions both on- and off-balance sheet [9]. The "market price" refers to the price of any instrument traded on an exchange. The different forms of market risk recognised in the amendment include: equity price risk (market and specific), interest rate risk associated with fixed income instruments, currency risk and commodities price risk. Debt securities (fixed and floating rate instruments, such as bonds, or debt derivatives), forward rate agreements, futures and options, swaps (interest rate, currency or commodity) and equity derivatives will expose a bank to market risk [10]. Market and credit risk can be closely linked. For example, if the rating of corporate or sovereign debt is upgraded/downgraded by a respected credit rating agency, then the corporate or sovereign bonds will rise/fall in value.

In the numerator of the Basel ratio, a third type of capital, tier 3 capital, can be used by banks but only when computing the capital charge related to market risk, and subject to the approval of the national regulator. Tier 3 capital is

\footnotetext{
1 Basel I - International Convergence of Capital Measurement and Capital Standards adopted 1988

2 Basel II - International Convergence of Capital Measurement and Capital Standards adopted 2004

3 Basel III - International Convergence of Capital Measurement and Capital Standards to be adopted in the future
}

defined as short-term subordinated debt, which meets a number of conditions stipulated in the agreement, including a requirement that neither the interest nor principal can be repaid if it results in the bank falling below its minimum capital requirement.

Whether the Amendment raises or lowers the capital charge of a bank depends on the profile of its trading book. Under the Amendment, one of two approaches to market risk can be adopted, internal models or standardised.

Now Lithuanian banks are switching to internal model approach, because in most cases, as discussed before, internal model approach is more suitable for modern bank. On the other hand, creating internal model for Lithuania banks requires more efforts in creating such models, additional attention to risk management and more qualified employees for creating and using internal VaR models.

In next chapters these two possible approaches will be discussed.

\section{The standardised approach}

Banks without an approved internal model for estimating market risk exposure are required to use Basel's standardised approach. No VaR computation is used. Instead, the amount of capital to be set aside is determined by an additive or building bloc approach based on the four market risks, that is, changes in interest rates (at different maturities), exchange rates, equity prices and commodity prices. In every risk category, all derivatives (e.g. options, swaps, forward, futures) are converted into spot equivalents. Once the capital charge related to each of these risks is determined, it is summed up to produce an overall capital charge. The computation does not allow for any correlation between the four market risks categories. To put it another way, portfolio diversification is not accepted as a reason for reducing the capital to be set aside for market risk.

A bank's net open position in each individual currency is obtained - all assets less liabilities, including accrued interest. The net positions are converted into basic currency at the spot exchange rate. The capital charge of $8 \%$ applies to the larger of the sum (in absolute value terms) of the long or short position, plus the net gold position.

On the other hand, the Central Bank of Lithuania sets additional limits for single currency and overall currencies exposure for commercial banking. Single foreign currency exposure cannot exceed $15 \%$ of bank capital; overall foreign currencies exposure cannot exceed $25 \%$ of bank capital.

Alternatively, subject to approval by national regulators, banks can use an internal model approach.

\section{Internal model approach}

Banks, subject to the approval of the national regulator, are allowed to use their own internal models to compute the amount of capital to be set aside for market risk, subject to a number of conditions. Usually VaR is calculated by different formulas, but common simplified formula for VaR 
calculation is presented below:

$$
\mathrm{VaR}=\alpha \sigma_{p} \sqrt{\Delta t},
$$

here: $\Delta t$-holding period; $\alpha$ - constant of confidence interval; $\sigma_{p}-$ standard deviation of portfolio.

Basel committee and the Central Bank of Lithuania has certain specific requirements to be satisfied for good VaR model [11]:

1. Bank models must compute VaR on a daily basis.

2. The four risk factors to be monitored are interest rates (for different term structures/maturities), exchange rates, equity prices and commodity prices.

3. Basel specifies a one-tailed $99 \%$ confidence interval, ie the loss level is at $99 \%$; the loss should occur 1 in 100 days or 2 to 3 days a year.

4. The choice of holding period ( $t$ in the equation above) will depend on the objective of the exercise. Banks with liquid trading books will be concerned with daily returns and compute DEAR, daily earnings at risk. Pension and investment funds may want to use a month. The Basel Committee specifies 10 working days, reasoning that a financial institution may need up to 10 days to liquidate its holdings.

5. Basel does not recommend which frequency distribution should be used. Banks that use variancecovariance analysis normally make some allowances for non-linearities, and the Basel Amendment requires that non-linearities arising from option positions be taken into account. For either approach, Basel II requires the specification of a data window, that is, how far back the historical distribution will go, and there must be at least a year's worth of data. Generally, the longer the data run, the better, but often the data do not exist except for a few countries, and it is more likely that the distribution will change over the sample period.

\section{VaR models}

Financial institutions are subject to many sources of risk. Risk can be broadly defined as the degree of uncertainty about future net returns. A common classification reflects the fundamental sources of this uncertainty. Accordingly, the literature distinguishes four main types of risk. Credit risk relates to the potential loss due to the inability of a counterpart to meet its obligations [12]. It has three basic components: credit exposure, probability of default and loss in the event of default. Operational risk takes into account the errors that can be made in instructing payments or settling transactions, and includes the risk of fraud and regulatory risks [13]. Liquidity risk is caused by an unexpected large and stressful negative cash flow over a short period. If a firm has highly illiquid assets and suddenly needs some liquidity, it may be compelled to sell some of its assets at a discount. Market risk estimates the uncertainty of future earnings, due to the changes in market conditions.

The most prominent of these risks in trading is market risk, since it reflects the potential economic loss caused by the decrease in the market value of a portfolio. Value at Risk (VaR) has become the standard measure that financial analysts use to quantify this risk. It is defined as the maximum potential loss in value of a portfolio of financial instruments with a given probability over a certain horizon. In simpler words, it is a number that indicates how much a financial institution can lose with given probability over a given time horizon. The great popularity that this instrument has achieved among financial practitioners is essentially due to its conceptual simplicity: VaR reduces the market risk associated with any portfolio to just one number, which is the loss associated with a given probability, as indicated by Rose [14].

VaR measures can have many applications, such as in risk management, to evaluate the performance of risk takers and for regulatory requirements. In particular, the Basel Committee on Banking Supervision at the Bank for International Settlements imposes to financial institutions such as banks and investment firms to meet capital requirements based on VaR estimates [15]. Providing accurate estimates is of crucial importance. If the underlying risk is not properly estimated, this may lead to a sub-optimal capital allocation with consequences on the profitability or the financial stability of the institutions.

From a statistical point of view, VaR estimation entails the estimation of a quantile of the distribution of returns. The fact that return distributions are not constant over time poses exceptional challenges in the estimation.

While VaR is a very easy and intuitive concept, its measurement is a very challenging statistical problem. Although the existing models for calculating VaR employ different methodologies, they all follow a common general structure, which can be summarized in three points:

1) Mark-to-market the portfolio.

2) Estimate the distribution of portfolio returns.

3) Compute the VaR of the portfolio.

The main differences among VaR methods are related to point, that is the way they address the problem of how to estimate the possible changes in the value of the portfolio. CAViaR models skip the estimation of the distribution issue, as they allow computing directly the quantile of the distribution. Existing models can be classified into three categories [16]:

- Parametric (RiskMetrics and GARCH).

- Nonparametric (Historical Simulation and the Hybrid model).

- Semiparametric (Extreme Value Theory, CAViaR and quasi-maximum likelihood GARCH).

\section{The VaR model for currency risk management}

For currency exchange risk management model based on variation/covariation method will be used. This method takes in account historical exchange rates data. Risk evaluation is done for every currency separately. The model will use simple VaR estimation formula:

$$
R_{i}=P_{i} \cdot \sigma_{i} \cdot K \cdot \sqrt{T},
$$


here: $P_{i}$ - value of the currency; $K$ - quantile, calculated based on confidence level; $T$ - time horizon; $\sigma_{i}$-standard deviation of exchange rate, calculated by formula 3 :

$$
\sigma_{i}=\sqrt{\frac{n \sum Y_{i}^{2}(t)-\left(\sum Y_{i}(t)\right)^{2}}{n(n-1)}},
$$

here: $n$ - amount of historical data per one calculation; $Y_{i}(t)$ - logarithmic changes of exchange rates, calculated using formula 4.

$$
Y_{i}(t)= \begin{cases}\ln \left(\frac{X_{i}(t)}{X_{i}(t-1)}\right) ; \\ \ln \left(\frac{1}{X_{i}(t-1)}\right), & \text { if } X_{i}(t)=0 ; \\ \ln \left(X_{i}(t)\right), & \text { jei } X_{i}(t-1)=0 .\end{cases}
$$

\section{Calculation of acceptable loss limits}

After calculating VaR value for each tradable currency acceptable loss limits should be calculated. First annual loss limit is set. Loss limits for other periods are calculated based on annual loss limit.

Half-year loss limit will be half of annual loss limit. Initial month loss limit will be half of half-year limit. Further month loss limit is calculated by formula:

$$
L_{m e n}=\left\{\begin{array}{l}
\frac{L_{\text {pusm }}}{2}, \quad \text { if }\left(\frac{p m R}{2}+p m L\right) \geq L_{\text {pusm }} \\
\frac{p m R}{2}+p m L, \quad \text { if }\left(\frac{p m R}{2}+p m L\right)<L_{\text {pusm }},
\end{array}\right.
$$

here: $L_{m e n}-$ month loss limit; $L_{\text {pusm }}$ - half-year loss limit; $p m L$ - last month loss limit; $p m R$ - trading result of last month.

Initial week loss limit is equal to half of month loss limit. Further week loss limit is calculated by formula:

$$
L_{\text {sav }}=\left\{\begin{array}{l}
\frac{L_{\text {men }}}{2}, \quad \text { if }\left(\frac{p s R}{2}+p s L\right) \geq L_{\text {men }} ; \\
\frac{p s R}{2}+p s L, \quad \text { if }\left(\frac{p s R}{2}+p s L\right)<L_{m e n},
\end{array}\right.
$$

here: $L_{m e n}$ - month loss limit; $L_{s a v}$ - week loss limit; $p s L$ - last week loss limit; $p s R$ - trading result of last week.

Initial day loss limit is equal to half of week loss limit. Further day loss limit is calculated by formula:

$$
L_{d}=\left\{\begin{array}{l}
\frac{L_{\text {sav }}}{2}, \quad \text { if }\left(\frac{p d R}{2}+p d L\right) \geq L_{\text {sav }} \\
\frac{p d R}{2}+p d L, \quad \text { if }\left(\frac{p d R}{2}+p d L\right)<L_{\text {sav }},
\end{array}\right.
$$

here: $L_{s a v}$ - week loss limit; $L_{d}$ - day loss limit; $p d L-$ last day loss limit; $p d R$ - trading result of last day.

\section{Open foreign currencies positions limits calculation}

Calculated loss limits must be converted into open foreign currencies positions limits, because this measure is mostly understandable by foreign exchange traders. Open foreign currencies positions limits calculations will be done using calculated day loss limit and calculated VaR for single currency.

Calculated day loss limit can be treated by different approaches, depending on financial institution or single trader needs. Two most popular approaches in Lithuanian commercial banks presented below.

- 8-hour approach. Usually in financial institutions active trading is done only 8 hours per day. Other time is considered as night time and during this time only little unmanaged exposures are left. In this approach day loss limit is divided into two parts: active trading limit (for example, $90 \%$ of day loss limit) and night trading limit (for example, $10 \%$ of day loss limit). Sum of these 2 limits should be equal to day loss limit. Open position limit for active trading is calculated with $8 \mathrm{~h}$ horizon and using calculated active trading loss limit. Open position limit for night trading is calculated with $16 \mathrm{~h}$ horizon and using calculated night trading loss limit.

- 24-hour approach. In other financial institutions is considered that active currency trading is performed $24 \mathrm{~h}$ per day (technically that is done by using all day working traders department or possibility for traders to make deals from their home). On the other hand, even if a financial institution is working only $8 \mathrm{~h}$ per day, traders usually sets stop orders in the market and trades can be completed in non-working hours of financial institution. Using this approach, open position limit is calculated with $24 \mathrm{~h}$ horizon and using calculated day loss limit.

Open position limit is calculated with selected time horizon and using calculated loss limit. If calculated open position limit is lower than actual open positions, then open positions can be enlarged and if calculated open position limit is higher than actual open positions must be lowered. Open foreign currencies positions limits are calculated by formula 8 :

$$
M A X P_{i}=\frac{\left(L-V A R_{L T L}\right)}{V a R_{i} \times K_{i}} \cdot P_{i},
$$

here: $M A X P_{i}-$ open single currency position limit; $V A R_{i}-$ VaR of single currency; $P_{i}-$ actual open single currency 
position; $L$ - loss limit; $V A R_{L T L}-$ sum of calculated VaR for all currencies; $K_{i}$ - exchange rate of single currency.

When open foreign currency positions limits are calculated, VaR model is completed and model should be backtested for accuracy with real FOREX market data. The proposed model can be considered as suitable for using in financial institutions if back-testing results will be positive.

\section{Back-testing of the VaR model}

The proposed VaR model will be back-tested using real FOREX market data. During back-testing will be tested if number of mismatches (when actual change in exchange rate is larger, than calculated by VaR method) is lower than calculated by confidence level.

Back-testing is done with eight main currencies pairs with EUR. These eight currencies (USD, GBP, JPY, CHF, $C A D, A U D, N O K, S E K$ ) are mostly used by FOREX traders for trading and speculation purposes. EUR was used as basic currency in back-testing model, because Lithuanian national currency Litas (LTL) is pegged to EUR and EUR is the basic currency for Lithuanian commercial banks, thus all trading results and risk values always should be converted to LTL or EUR in Lithuanian financial institutions.

Back-tested model is variation/covariation VaR model, thus such type of models has some key parameters. Key parameters for back-tested model are presented in Table 1.

Back-tested model uses $95 \%$ of confidence level, thus mismatches percentage should be lower than $5 \%$. Time horizon is used 24 hours (reasons for such time horizon are discussed above) and calculation is done by 1000 points of
Table 1. Main parameters of back-tested model

\begin{tabular}{|l|c|}
\hline \multicolumn{1}{|c|}{ Parameter } & Value \\
\hline Confidence level & $95 \%$ \\
\hline Time horizon & $24 \mathrm{~h}$ \\
\hline $\begin{array}{l}\text { Historical data amount for } \\
\text { VaR calculation }\end{array}$ & 1000 \\
\hline Data period & $1 \mathrm{~h}$ \\
\hline Back-testing period & $01-11-2004-31-07-2006$ \\
\hline
\end{tabular}

historical data. It is considered that 1000 data points is optimal amount for back testing [17]. For a precise calculation it is recommended to use as much as possible data points, but, when we apply too much data points, the calculation becomes very slow even for most modern computers.

That is why mismatches percentage higher than $3 \%$ are outlined in the Table 2. If mismatches percentage is higher than $3 \%$ mismatches analysis should be done.

For model back-testing hourly FOREX data is used, because time horizon measure (in hours) and data period should be the same. Back-testing period is 01-11-200431-07-2006.

Large number of mismatches would show that the proposed VaR model is not accurate enough and should be reconstructed to make it more precise. During back-testing recorded mismatches number alone does not mean that the VaR model is good or bad. Thus the main factor for judging the VaR model is the percentage of mismatches compared with cases studied during a period. For mismatches percentage analysis, one month period was used and all back-

Table 2. VaR model back-testing results

\begin{tabular}{|c|c|c|c|c}
\hline Data & USD, $\%$ & GBP, $\%$ & JPY, $\%$ & CHF, $\%$ \\
\hline 112004 & & 0,51 & & 4,85 \\
\hline 122004 & & 1,04 & 0,52 & \\
\hline 012005 & 0,58 & & 0,19 & \\
\hline 022005 & & & & \\
\hline 032005 & 0,38 & & & \\
\hline 042005 & & & 3,52 & 1,37 \\
\hline 052005 & & 1,49 & & \\
\hline 062005 & & 0,84 & & \\
\hline 072005 & & 0,83 & 1,93 & \\
\hline 082005 & 2,60 & 2,74 & 2,74 & \\
\hline 092005 & & & & \\
\hline 102005 & 0,29 & 0,29 & & \\
\hline 112005 & 0,83 & 0,83 & 0,14 & \\
\hline 122005 & 0,67 & 0,40 & 1,61 & 0,54 \\
\hline 012006 & 1,48 & & 0,27 & 0,13 \\
\hline 022006 & 2,71 & 3,18 & 3,98 & 3,18 \\
\hline 032006 & & 0,27 & 0,54 & \\
\hline 042006 & 1,67 & 0,14 & 0,83 & 2,78 \\
\hline 052006 & 1,22 & 0,41 & 1,36 & 1,22 \\
\hline 062006 & 0,42 & 0,28 & & \\
\hline 072006 & 0,40 & 0,94 & & 0,40 \\
\hline
\end{tabular}


Table 3. The back-testing results of the VaR model

\begin{tabular}{|c|c|c|c|}
\hline Currency & $\begin{array}{c}\text { VAR } \\
\text { mismatches }\end{array}$ & Studied cases & $\begin{array}{c}\text { Mismatches } \\
\text { percent }\end{array}$ \\
\hline USD & 92 & 12068 & 0,76 \\
\hline GBP & 94 & 12068 & 0,78 \\
\hline JPY & 116 & 12068 & 0,96 \\
\hline CHF & 83 & 12068 & 0,69 \\
\hline CAD & 110 & 12068 & 0,91 \\
\hline AUD & 94 & 12068 & 0,78 \\
\hline NOK & 78 & 12068 & 0,65 \\
\hline SEK & 133 & 12068 & 1,10 \\
\hline
\end{tabular}

testing period was divided into months. In Table 2, mismatches percentage during each back-tested month is presented.

In Table 2, the back-testing results are presented, which should be considered as positive. Back-tested model use $95 \%$ confidence level, hence the percentage of mismatches should be lower than $5 \%$ and in all cases mismatches percentage was lower than $5 \%$.

In Lithuanian financial institutions, it is considered that "good" VaR model should have less than $3 \%$ mismatches.

The analysis of mismatches showed that all recorded mismatches can be classified into 3 categories:

- Real mismatches - after a sudden change of exchange rate calculated change by the VaR model was smaller than actual.

- Holiday mismatches - during public holidays FOREX market is closed, but fundamental events do happen and they influence exchange rates. In such cases exchange rate after public holiday opens with the gap and mismatch is recorded.

- Bad data mismatches - FOREX market data (especially free data) is not completely clear. In such data some little or large mistakes exist. They usually generate mismatches, which are completely false.

Mismatches analysis showed that part of mismatches are false or partly false, hence back-testing results are positive. For overall results Table 3 was created. In this table mismatches percent age during all back-testing period was calculated. This analysis showed that overall mismatch percentage is extremely good and only one currency pair (EUR/SEK) has mismatch percentage higher than $1 \%$.

The VaR model back-testing showed that proposed VaR model is precise enough and suitable for everyday use.

\section{Conclusions}

Lithuanian commercial banks now are in transitional period adopting their risk management systems to Basel II requirements. Market risk is considered one of the key risks in bank risk management structure, thus proper management of market risk is essential for a modern bank. Currency exchange risk usually is main component of market risk. Currency exchange risk management in Lithuanian commercial banks was not good enough; also central bank regulatory limits were liberal. But now the entire risk management system is transforming and currency exchange risk management is affected.

In this article currency risk management using Valueat-Risk (VaR) methods is presented. VaR models are known as very innovative and as a new approach to risk management issues. Using these models risk value can be calculated and loss limits can be set to limit risk exposures. Using VaR methodology, universal risk measures can be used, so it is possible to compare different traders, instruments and trade areas. VaR results are very clear and understandable to everyone, but calculation process can be hard and complicated. Risk value is used in most financial institutions all over the world.

In this article variation/co-variation VaR model and implementation guidance is presented. This model (also known as parametric, delta normal or analytic) treats currency rates data series as distributed by normal distribution. This method has advantages and disadvantages and is considered as a good method for currencies with low volatility calculations.

The proposed model was tested with real data using back-testing method. Back-testing showed that proposed model is reliable enough, because number of mismatches was less than $5 \%$ in all tested currency pairs during all testing periods. In most currency pairs mismatches percent was lower than $3 \%$.

The back-testing results confirm that the VaR method is reliable enough and suitable for day-to-day us age by financial institution or trader.

\section{References}

1. HEMPEL, G. H.; SIMONSON, D. G.; COLEMAN, A. B. Bank management: text and cases. New York etc: Wiley, 1994.

2. BESSIS, J. Risk management in banking. England, 1998.

3. GALLATI, R. Risk management and capital adequacy. USA: The McGraw-Hill Companies, 2003.

4. OLSSON, Carl. Risk management in emerging markets. Great Britain: Pearson Education Limited, 2002.

5. PYLE, H. D. Bank risk management: Theory. In Conference on risk management and regulation in banking. 1997.

6. Van GREUNING, H.; BRAJOVIC BRATANOVIC, S. Analysing and managing banking risk: a framework for assessing corporate governance and financial risk. 2nd ed. Washington: The World Bank, 2003.

7. RUDŽIONIENĖ, K. Impact of stakeholders' interests on financial accounting policy-making: The Case of Lithuania. Transformations in Business \& Economics, 2006, Vol 5, No 1(9), p. 51-64.

8. HEFFERNAN, S. Modern banking. John Wiley \& Sons Ltd, The Atrium, Southern Gate, Chichester, 2005.

9. KANCEREVIČIUS, G. Finances and investments. Kaunas: Smaltijos leidykla, 2004 (in Lithuanian).

10. FREITAKAS, F.; ŽIGIENĖ, G.; GRIGAITIS, A. The PAD phenomenon in the UK capital market. Transformations in Business \& Economics, 2006, Vol 5, No 1(9), p. 148-165.

11. Bank of Lithuania (2002) Decision No 151 "On methodologi- 
cal recommendations for banks when applying internal models of market risk". Published 20021128 (in Lithuanian).

12. BIELECKI, R.T., RUTKOWSKI, M. Credit risk: modeling, valuation and hedging. New York: Springer-Verlag, 2000.

13. RITTER, L.; UDELL, G. Principles of money, banking, and financial markets. Addison Wesley, 1997.

14. ROSE, P. S. Commercial bank management: producing and selling financial services. Homewood (IL) Boston: Irwin, 1993.
15. RANONYTÉ, A. Basel II: A challenge for banks is getting momentum. Verslo žinios, 2005, Nr. 1(12), p. 4-5 (in Lithuanian).

16. MANGANELLI, S.; ENGLE, F. R. Value at risk models in finance: Working paper. Frankfurt am Main: European Central Bank, 2001.

17. BERKOWITZ, J.; O'BRIEN, J. How accurate are value-atrisk models at commercial banks? 2006.

\section{VALIUTU KEITIMO RIZIKOS VALDYMO TRANSFORMACIJOS LIETUVOS KOMERCINIUOSE BANKUOSE}

\section{J. Nedzvedskas, P. Aniūnas}

Santrauka

Straipsnyje pateikiamas naujas vertès rizikos (VR) modelis valdant valiutų keitimo riziką. Tai buvo išbandyta realiomis rinkos sąlygomis Lietuvos komerciniuose bankuose. Daroma išvada, kad pasiūlytas metodas yra veiksmingesnis negu buvę valiutų keitimo rizikos valdymo metodai, kuriuos Lietuvos bankas pritaikè pagal Bazelio II nuostatas.

Reikšminiai žodžiai: valiutos keitimo rizika, vertès rizika (VR), Bazelio komitetas, komercinė bankininkystė, Lietuva.

Jonas NEDZVEDSKAS. Dr, Assoc Prof at Faculty of Economics and Law, Kaunas College (Lithuania). His lecturing career extends to Lithuanian higher schools, such as Vilnius University and Kaunas University of Technology. Fields of scientific interests include financial management, banking, monetary policy, accountancy.

Povilas ANIŪNAS. Last year PhD student at the Dept of Finance and Accounting, Kaunas Faculty of Humanities, Vilnius University (Lithuania). The assumed date of the defense of the $\mathrm{PhD}$ dissertation in Economics is autumn of 2007. A long-term practice working in commercial enterprises, currently, employed by the bank AB "Hansabankas". The author is interested in financial forecasting methods, risk management in currency exchange mechanism, commercial banking. 